\title{
TEACHER OF CHRISTIAN RELIGION EDUCATION, QUALITY OF EDUCATION AND THE FUTURE OF THE MORALITY OF THE NATION OF THE FIRST
}

\author{
Writer (1), Second Writer(2), Third Writer (3), Fourth Writer (4), Fifth Writer(5) \\ 1) Urbanus Sukri E-mail: whenitamerliani@gmail.com \\ 2) Simeon Sulistyo \\ E-mail : simeonsulistyo@gmail.com \\ 3) Desire Karo karo \\ E-mail: blessingkaban @ gmail.com \\ 4) Indro Puspito \\ E-mail : indropuspito@gmail.com \\ 5) Theresia Christina \\ E-mail : tchristinaa21@gmail.com
}

\begin{abstract}
This paper aims to provide an understanding that Christian Education teachers have a significant role in improving the quality of education and the future of national morality. The development of globalization and modernization makes teachers must be ready and contribute in preparing the nation's young generation in entering the era of globalization and modernization. At least there are two roles that must be possessed by the Christian Religious Education teacher, namely participating in realizing quality education and maintaining the nation's morality. With this writing, it is expected that every Christian Education teacher will become more aware and more enthusiastic in carrying out his duties and vocation as a teacher of Christian Religious Education.
\end{abstract}

Keywords: Teachers, Christian Education, Quality of Education, Future, Nation Morality

\section{A. Introduction}

The Indonesian nation will not be able to avoid the brunt of the flow of globalization and modernization. Ready or not this nation will face it. The challenges of globalization and modernization are in sight. ${ }^{1}$ One side of globalization and modernization is a blessing for the Indonesian people. But on the other hand there are not a few negative effects that accompany it.

There are two important roles of Christian Religious Education teachers in their efforts to be involved in preparing young people in entering the era of globalization and modernization. First, participate in realizing quality education. And second, safeguard the nation's morality from the onslaught of global secularism which results in the moral degradation of future generations. Then how does the Christian Religious Education teacher play a good role in both cases?

\section{B. Christian Education Teachers and Educational Quality}

In the teaching and learning process there are at least four important components that must be included in it. Teachers, students, curriculum, and infrastructure. If one is lost, the teaching and learning process will be disrupted, and become less perfect. "Without classes, buildings, equipment and so on, the education process can still run even in an emergency, but without the teacher the education process is almost impossible to run," wrote Sukmadinata. $^{2}$ Aminatul Zahroh believes that teachers are one of the components determining the 
success of education. ${ }^{3}$ For Syaiful Bahri Djamarah, the teacher is a human figure who occupies a position and plays an important role in education. ${ }^{1}$ This can be understood because the teacher is dealing directly with students in class. The teacher is at the forefront of the intellectual life of the nation.

In the introduction of the Republic of Indonesia Law No. 14 of 2005, wrote that teachers and lecturers have a very strategic function, role and position in national development in the field of education. ${ }^{2}$ In an explanation of the introduction of the Law of the Republic of Indonesia No. 14 of 2005, it was explained that among the nine missions of professionalism of teachers and lecturers, two of them were related to improving the quality of learning and education. The two reads: ${ }^{6}$

- Improving the quality of learning;

- Improve the quality of national education;

Explanation of Government Regulation of the Republic of Indonesia No. 74 of 2008 concerning Teachers, said that professional teachers will produce quality education processes and results. . . 3 Therefore judicially there is support for the thesis which says that there is a teacher's influence on the quality of education. ${ }^{4}$ The book entitled "Teacher Competency Standards and Certification", written by Enco Mulyasa, explains that there are findings from the results of a literature review that show that teachers have a very strategic role and determine the success of education and improve the quality of learning, and shape the competencies of students. ${ }^{5}$ This is supported by Sudarwan Danim, saying that one element of the capacity to improve the quality of

${ }^{1}$ Syaiful Bahri Djamarah,students Teachers andin educational interactions. (Jakarta: PT Rineka Cipta), 2010, p. 1.

${ }^{2}$ Republic of Indonesia Law Number 14 of 2005 and 2014 Republic of Indonesia Minister of Education and Culture Regulation concerning Teachers and

Lecturers.(Jakarta: Citra Umbara Publishers, 2015), p.2. ${ }^{6}$ Ibid., P.43.

${ }^{3}$ Ibid., P.107.

${ }^{4}$ The word teacher here represents all subject teachers. Among them are teachers of Christian Education subjects. So it

was concluded that the Christian Religious Education Teacher greatly influenced the quality of learning in the class and national education quality.

${ }^{5}$ Enco Mulyasa, Competency Standards and Teacher Certification. (Bandung: PT Remaja Rosdakarya, 2012), p. 8 . schooling education is professional teachers. ${ }^{6}$ The teacher is one component that determines the success of education. ${ }^{7}$ Another expert, Wina Sanjaya, explained that among the four components above (Teachers, students, curriculum, and facilities), the component of the teacher who had been most considered to have greatly influenced the education process. $^{8}$

Why is that? This is reasonable according to Wina Sanjaya, because the teacher is the spearhead that deals directly with students as subjects and objects of learning. ${ }^{9}$ Besides this, the teacher is a very decisive component in the implementation of a learning strategy. The successful implementation of a learning strategy will depend on the expertise of the teacher in using methods, techniques, and learning tactics. ${ }^{10}$

So we can be sure that the success of a student in learning is a big part of the hard work of a teacher. And this affects the success of the implementation of education as a whole. So it is clear to us that the development and progress of education in a country is strongly influenced by the ability of the teacher. Among the thousands of teachers there must be a teacher of Christian Religious Education in it. The conclusion is that the service of Christian Religious Education teachers in the learning process greatly influences the quality of the nation's education.

\section{B. Christian Religious Education Teachers and the Future of Nation Morals}

From the description above it has been concluded that the Christian Religious Education teacher is a personal figure who is very influential in the success of learning a student. Students'

success in learning is an indicator of the success of a nation's education. The success of education enlightens the future of a nation. If a country has a very high level of learning success, it can be

\footnotetext{
${ }^{6}$ Sudarwan Danim, Teacher Professional

Development. (Jakarta: Prenada Media Group, 2011), p. 100.

7 Zahroh, Ibid., P. 1.

${ }^{8}$ Wina Sanjaya, M.Pd, Curriculum and Learning.

(Jakarta: Kencana Prenada Media Group, 2010), p. 273.

${ }^{9}$ Ibid.,

${ }^{10}$ Ibid., P. 52.
} 
ascertained that the country belongs to the category of developed countries.

Science and technology are produced by developed countries. Science and technology are a means of achieving a nation's glorious future. And this is a service from the teachers. The role of the teacher is so important for the existence of the nation in the future. ${ }^{11} \mathrm{JVS}$. Tondowidjojo, CM quoted Napoleon as saying, "The fate of the land lies in your hands, and its future lies in the hands of your children, while those children form it." 12 So the future of the young generation lies in the hands of the teacher.

Then what is the role of the Christian Religious Education teacher in building the future of a nation, specifically the Indonesian people? In the future there will be a very rapid development of science and technology. The development and progress of science and technology have two effects, namely positive and negative. Positive impact is that life becomes more effective and efficient. All human activities and problems will be solved easily. Humans can save energy, space, time, distance, costs, etc. Life will be easier. Life is full of creative and varied things, and does not tend to be monotonous (boring). Making life more enjoyable like the slogan of one particular brand of cigarette product, "make life more alive." But there are also negative impacts on human life, and this is important to watch out for and watch out for. With the development of science and technology, if uncontrolled humans can become like God. Acting beyond the limits of human nature. Become God for yourself, and God for others. With knowledge and technology, they can do what they want. Especially in terms of crime. Crimes will arise with a very creative mode. What is that ? Maybe this time has not been imagined. But later we will be surprised to hear and see that happen. One example of the prediction of the negative impacts of technological advances produced by science in this global and modern era, Fidian Rahman, a Muslim observer, wrote to the younger generation in one of the social media accounts. He wrote as follows: ${ }^{17}$

\footnotetext{
${ }^{11}$ Aminatul Zahroh, Iid., P. 32.

12 JVS. Tondowidjojo, CM, Key to

Success of Educators. (Yogyakarta:

Kanisius, 1988), p. 48. ${ }^{17}$ Teen

Sampit blogsport.com.
}

\section{Pornography}

Because of the ease and development of the internet. We can find anything in cyberspace, including pornography. Apparently not only adults who access pornographic sites, many also from teenagers and children who turned out to access many of these sites. Addiction to pornography is a very serious thing, this can reduce human morals.

\section{The emergence of Fake Accounts}

Fake accounts or more commonly known as anonimous certainly very much found in cyberspace. Nonimous sometimes do things that violate communication ethics. Nonimous also often destroys the internet network system of an important institution of the country. Besides damaging the anonymous too often giving terror or threats that harm society.

\section{False Identity}

False accounts appear on social networks such as Facebook, Twitter, Yahoo, etc. with various purposes, for example to harass good reputation, take advantage of others, damage family relationship and many more actions done by fake accounts that harm people. Either harming the individual or harming the public.

\section{Personal Account Piracy}

The development of technology also makes criminals in the information world more sophisticated in their actions, important account hijackers can be done, such as hijacking passwords, ATMs, banks, etc. Personal data can also be revealed to the general public, harassment can also occur with piracy of this account,

\section{Excess Information}

The information we receive so much makes us unable to properly filter out any information that has a positive and negative impact

\section{Game Addiction}

Game is one of the technologies favored by teenagers and children. with fun they play games, over time they are addicted and increasingly 
dependent on games, this can damage the development and growth of children.

\section{Forgetting Obligations}

Technology cannot be denied that we have forgotten our obligations, both obligations to the world and obligations to the hereafter, such as learning, helping parents, praying. recite and other obligations.

\section{Harmful Radiation}

Technology tools such as mobile phones, monitors, PCs cause radiation and can cause health problems if used too long without rest. There are a number of diseases caused by radiation in excessive technological devices.

\section{The emergence of gaps}

For those people who understand and understand technology, they will continue to add insight into technology, while those who are left behind in technology will be increasingly left behind, This can create a gap.

\section{Destruction of Original Culture}

The flow of technology that goes on endlessly brings new cultures and destroys existing indigenous cultures. Indonesian is more sidetracked, and more important slang languages, etc.

\section{Loss of National Identity}

Technology and information from various parts of the world enter quickly into Indonesia, so that technology users will gradually change their lifestyles like western people . and gradually the Indonesian identity will disappear.

\section{Plagiarism}

Copy Paste is no longer a strange phenomenon in cyberspace, many plagiarism has emerged and acknowledged a work that is not his own work. This can lead to a loss of appreciation for someone who works.

\section{Decreasing of relationship}

Humans are increasingly preoccupied with work and more often dwell on the computer. Humans appreciate time as money. This certainly can be a trigger for the looseness of relationships between neighbors and other friends.

\section{Various Crimes in cyberspace}

There have been many criminal acts that have taken place in cyberspace, whether openly or clandestinely, for example: gambling, lottery, illegal limb sales, narcotics, pornography, harassment, sales etc. This is just a prediction, it will be more shocking and shocking. People's future behavior ${ }^{13}$ has been prophesied in the Bible (New Testament), as written in the letter 2 Timothy 3: 1-7. The Apostle Paul said that future humans will experience difficult times. Humans in the future, it would be:

- Lovers of themselves

- Lovers of money

- Boastful

- Arrogant

- Blasphemers

- Disobedient to parents

- Ungrateful

- Unholy

- Unloving

- Irreconcilable

- Slanderers

- Without self-control

- Savage

- Opposed to what is good

- Treacherous

- Reckless

- Conceited

- Loving pleasure rather than loving God

- They will maintain the outward appearance of religion but will have repudiated its power

- Captivate weak women who are overwhelmed with sins and led along by various passions,

- Always seeking instruction, yet never able to arrive at knowledge of the truth,

Thus the prophet Paul's prophecy about humans in the future. Then what is needed by this nation, especially people believe in facing events that will happen in the future. Well, here we need biblical

${ }^{13}$ The biblical term is the end of time. Here, the author sees that there is relevance, enter 2 Timothy $3: 1-7$ as a study material about the future. At the time of the writer. This global and modern era is a time that leads to the end of time. 
faith to equip the young generation of Christians who are the nation's future candidates to be ready and able to live and be able to control behaviors that are contrary to God's word caused by the progress of the age. If this is not balanced by the development of faith and the attitude of biblical religiosity, it will adversely affect the future of the nation. And this is the duty of the servants of God to instill Bible truths, including the teacher of Christian Religious Education. The servants of God, including the teacher of Christian Education are guardians of the biblical faith and ethics of the Christian youth. So without them they can already be imagined to be what the younger generation of Christians will be in the future.

The younger generation of Christians who hold to faith, and biblical ethics will be able to guard their mentality and morality from the negative influence of science, technology and excessive humanistic attitudes from humans. And they are able to maintain the nation's morality in accordance with the ideology of the country. from the young generation who behave biblically, is the work of the servants of God in which there are teachers of Christian Religious Education. Therefore professionalism of Christian Education teachers greatly influences the younger generation of Christians in the future who are expected to maintain the mentality and morality of the nation. Then the Christian Religious Education teacher has a very significant role in preparing the nation's morality to fit the biblical faith.

\section{Conclusion}

Country of Indonesia is moving towards a modern country. One characteristic of the modern state is the rapid development of science and the population who are already accustomed to the use of sophisticated technology. The community lives with everything digital. In addition to their wives or husbands, they regard computers as their mate Most important in the life of modern society is advanced technology.

To get there, many things are needed, which must be prepared by this nation. Among them are quality and quality education. Quality and quality education is produced from professional educators. Therefore their role is very important in realizing Indonesia as a modern country.

The Christian Religious Education teacher is one of the community educators who participates in realizing quality and quality education. Christian Religious Teachers along with nonChristian Religious Education teachers hand in hand work hard to equip themselves in an effort to become professional teachers who are ready to realize quality and quality education.

Being a modern country does not mean without problems. The problem of moral degradation is the main enemy of the people living in modern countries. Not a few modern countries in the world experience it. Free sex, a decrease in people's feelings for parents, crime, etc. are examples of the morality that afflicts the modern state.

The Christian Religious Education teacher plays a very important role in minimizing the decline of national morality. Christian Education Teachers teach about faith, biblical ethics. Through the study of Christian (biblical) faith and ethics, the young generation will realize the importance of holding fast to the Bible. Because it will fortify them from the onslaught of modern secularism that results in moral depravity of the nation's young generation, in the Indonesian nation.

Thus the important role of Christian Religious Education teachers in realizing quality education and inhibits the development of the nation's moral degradation.

\section{REFERENCES}

Aqib. Zainal and Elham Rahmanto, Building Professionalism for Teachers and School Supervisors. Bandung: YramaWidya, 2007.

Damin, Sudarwan, Teacher Professional Development. Jakarta: Prenada Media Group, 2011

Djamarah, Syaiful Bahri,students Teachers andin educative interactions. Jakarta: PT Rineka Cipta, 2010

Fathurrohman.Pupuh and Aa Suryana, MM, Professional Teachers. Bandung: PT Refika Aditama, 2012.

JVS. Tondowidjojo, JVS, CM, Key to Success of Educators. Yogyakarta: Kanisius, 1988

Mulyasa, Enco, Competency Standards and Teacher Certification. Bandung: PT. Teenagers Rosdakarya, 2012 
Rahman.Muhammat, and Sofan Amri, Kode

EtikProfession Teacher. Jakarta:Achievement, 2014.

Sagala, Syaiful, Professional Ability of Teachers and Education Personnel.LibraryContents:

ALFABETA, 2011.

Sanjaya, Vienna, Curriculum and Learning. Jakarta: Kencana Prenada Media Group, 2010 Udin Saefudin Saud, Teacher Professional Development. Bandung:

Alfabeta Publisher, 2011.

Republic of Indonesia Law Number 14 Year 2005 and 2014 Republic of Indonesia Minister of Education and Culture Regulation concerning Teachers and Lecturers. Jakarta: Citra Umbara Publishers, 2015

Yamin.Martinus, Teacher Professionalization \& KTSP Implementation.Jakarta: GaungPersada Press, 2008.

Zahroh, Aminatul, Building Learning Quality through the Dimensions of Teacher Professionalism. Bandung: Yrama Widya, 2015 